\title{
Hydro-Geochemical Characteristics and Health Risk Evaluation of Nitrate in Groundwater
}

\author{
Jianmin Bian ${ }^{1 *}$, Caihong Liu1, Zhenzhen Zhang', Rui Wang², Yue Gao \\ ${ }^{1}$ Key Laboratory of Groundwater Resources and Environment, Ministry of Education, Jilin University, \\ Changchun 130021, China \\ ${ }^{2}$ Shijiazhuang University of Economics, Shijiazhuang 050031, China
}

Received: 17 April 2015

Accepted: 21 December 2015

\begin{abstract}
Groundwater is considered a major source of drinking water and its quality a basis for good population health. In order to identify groundwater hydro-chemical characteristics and pollution conditions in Songnen Plain, groundwater hydro-chemical characteristics and nitrate-nitrogen $\left(\mathrm{NO}_{3}-\mathrm{N}\right)$ spatial distribution characteristics and the health risks were analyzed. Results showed that groundwater hydro-chemical type was mainly $\mathrm{HCO}_{3}-\mathrm{Ca}$, which was associated with the action of calcite and silicate mineral weathering dissolution. The over standards rate of $\mathrm{NO}_{3}-\mathrm{N}$ accounted for $50.8 \%$, the coefficient of variation was $183.57 \%$ which was high spatial variability, the high-risk area accounted for $88.78 \%$ of the total study area, and the high-risk area covered the area with water quality of classes IV, V, and part of class III. The high-risk area is mainly distributed in the eastern high plains and in the central low plains, while the low-risk zone accounts for only $11.22 \%$ of the total area and is mainly distributed in the western alluvial plain with scattered distribution in other areas.
\end{abstract}

Keywords: health risk evaluation, hydrochemical type, Piper trilinear charts, spatial variability, nitrate nitrogen

\section{Introduction}

As a valuable freshwater resource, groundwater plays an important role in many fields from domestic life to industrial and agricultural water supply, and its safety directly affects residents' physical health and quality of life [1-2]. In recent years, groundwater pollution becomes more and more serious with large-scale agricultural activities, the discharge of industrial wastewater containing

*e-mail: bianjianmin@126.com nitrogen, and urban living sewage [2-4]. Such pollution causes more serious problems in areas where groundwater is the main source of drinking water. In the early 1990s, research indicated that 0.8 million people in France were threatened by nitrate-polluted drinking water, 0.85 million in the UK, and 2.5 million in Germany [5]. Thus, issues of groundwater quality are gradually attracting more attention from researchers worldwide [2, 6-7]. Subsequently, many scholars carried out large-scale studies on the detection, prevention, and control of nitrogen in groundwater, and the three types of nitrogen-composed elements (nitrate, nitrite, and ammonium nitrogen) have become topics 
of global concerns for groundwater pollution [8-11]. At present, many countries have subsequently launched research and evaluation programs on nitrate pollution of groundwater to establish basic data for effectively controlling groundwater pollution [11-12].

Groundwater in many areas of China has been polluted by nitrate to various extents, and presents a deteriorating trend. Research on the various forms of nitrogen pollution started rather late in China and currently focuses on identifying the sources of the pollutants by means of isotope analysis [13-14]. As one of the three major plains in northeastern China, Songnen Plain is an important basin for large-scale production of commodity grain and animal husbandry. The study area is located in the central part of the Northeastern Plain, and has a semi-arid, sub-humid continental monsoon climate. The total water resource volume in the study area is $132.88 \times 10^{8} \mathrm{~m}^{3}$, of which the allowable groundwater extraction is $79.10 \times 10^{8} \mathrm{~m}^{3}(59.53 \%$ of gross water resources). Therefore, groundwater is an important source of water for this region [15]. Some locations have experienced water pollution problems in recent years, resulting from a combination of natural conditions, geological setting, and human activities. For example, excessive pumping of groundwater will bring about runoff from river and floodplains toward over-exploited areas, which could result in abnormal hydro-chemical conditions [16]. Furthermore, the toxic substances from agricultural irrigation and fertilization would infiltrate the groundwater together with the runoff, threatening the safety of drinking groundwater and agricultural production. The problem of excessive nitrogen concentration is especially serious. Therefore, it is critical to evaluate the risks associated with spatial variability of nitrogenous pollution in groundwater in order to ensure the safety of groundwater [17].

Although previous studies have examined the distribution and sources of groundwater, there are few studies of the risks to human health associated with nitrogen pollution of groundwater. Therefore, it is necessary to conduct health risk assessment on the basis of analyzing the spatial variability of nitrogen concentrations. This study collected groundwater samples in Songnen Plain in recent years. The chemical properties and evolving trends of groundwater in the area are examined via statistical and chemical analysis. The spatial variability of nitrate nitrogen in groundwater is analyzed via a semi-variogram, producing a health-risk assessment model associated with groundwater quality, and providing theoretical references for containment and management of nitrogen pollution in groundwater as well as sustainable development in the region.

\section{Materials and Methods}

\section{Background of the Study Area}

Songnen Plain is located in northeastern China (geographical coordinates $44^{\circ} 38^{\prime} 57^{\prime \prime}-49^{\circ} 16^{\prime} 14^{\prime \prime} \mathrm{N}$, $\left.122^{\circ} 59^{\prime} 05^{\prime \prime}-128^{\circ} 14^{\prime} 12^{\prime \prime} \mathrm{E}\right)$. Overall, it covers a total area of $18.71 \times 10^{4} \mathrm{~km}^{2}$ [18]. It has a semi-arid, sub-humid continental monsoon climate. The Nenjiang, Songhua, and Lalin rivers make up the southern boundary. Songnen Plain has high elevation on all sides and gently slopes inward to lower elevation at its center, forming a semienclosed asymmetric basin-shaped terrain that presents a north-northeast-extended diamond [19]. The inner topography can be divided into three parts: plateau plain in the east, low plain in the middle, and inclined piedmont plain in the west [20]. Songnen Plain has a temperate continental monsoon climate, presenting semi-humid and semi-arid features. Precipitation and humidity decrease, whereas evaporability and dryness increase from the east and northeast to the west and southwest. The semi-humid climate in the east and northwest gradually gives way to a semi-arid climate in the west and southwest. The research area is within the Songhua River system. Southeast of the Second Songhua River and northwest of the Nen River the two waterways converge in the middle of the plain, constituting the Songhua River, into which flow the Lalin and Hulan rivers, which subsequently flow east across Sanjiang Plain [19].

\section{Sampling and Test}

In order to illustrate the groundwater hydro-chemical characteristics and nitrogen pollution conditions, 279 samples (Fig. 1) were collected from 2011 to 2013, and tested in the laboratory of the Heilongjiang Province Hydrogeology and Environmental Geology Investigation Institute. The tested parameters included $\mathrm{Na}^{+}, \mathrm{K}^{+}, \mathrm{Ca}^{2+}$, $\mathrm{Mg}^{2+}, \mathrm{Cl}_{-}, \mathrm{SO}_{4}^{2+}$, total dissolved solids, $\mathrm{pH}$, total hardness, and the three forms of nitrogen $\left(\mathrm{NH}_{4}^{+}, \mathrm{NO}_{3}^{-}, \mathrm{NO}_{2}^{-}\right) . \mathrm{Na}^{+}$and $\mathrm{K}^{+}$were tested by flame photometric method; $\mathrm{Ca}^{2+}, \mathrm{Mg}^{2+}$, and total hardness were tested by EDTA complex titration method; Cl- was tested by standard solution titration

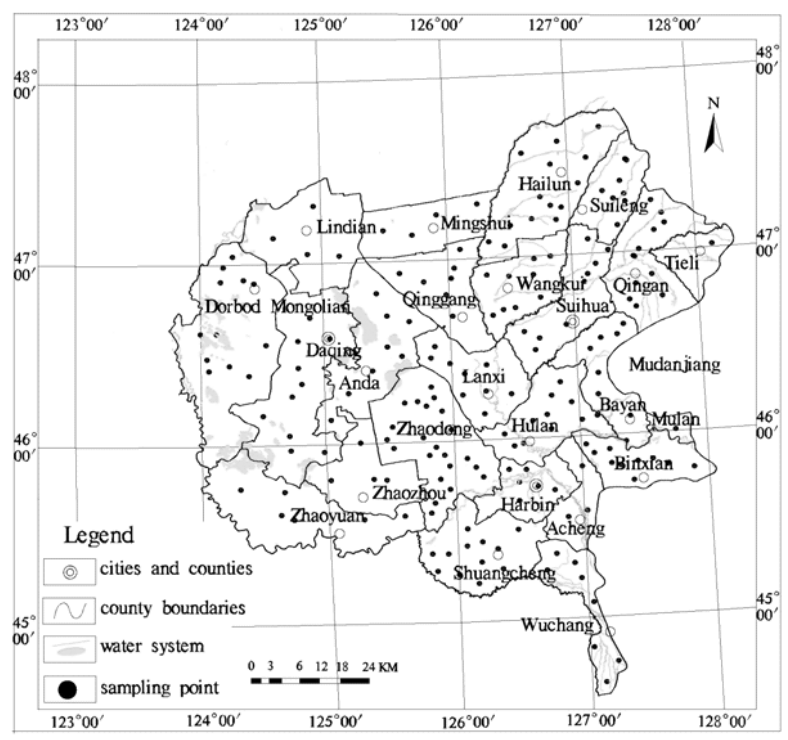

Fig. 1. Spatial distribution of sampling locations in the study area. 
with silver nitrate method; $\mathrm{pH}$ was tested by a $\mathrm{pH}$ meter; $\mathrm{NH}_{4}^{+}, \mathrm{NO}_{3}^{-}$, and $\mathrm{NO}_{2}^{-}$were tested by spectrophotometric method. Quality assurance and quality control were conducted according to "Standard for Assessment and Investigation of Groundwater Pollution" (DD200801 ), using the method of adding standard recovery and extracting repeated samplings to control quality.

\section{Data Analysis}

\section{Mathematical Statistics and Analysis Software}

The characteristics of groundwater hydrochemistry are analyzed via Statistical Package for the Social Sciences (SPSS). The ion index method is used to detect ion genesis and evolution, and Aqueous Geochemical Analysis (AquaChem) is favorable to discuss the water type and features by Piper trilinear chart [21-22].

Semi variance function and theoretical model: the semivariance function is an important function that mainly expresses spatial correlation between regional variables and can be used to study the spatial distribution randomness and structure of attributes quantifying the dispersion of all observations below the mean or target value in the data set [23-24]. The semivariance function is expressed as:

$$
\gamma(h)=\frac{1}{2 N(h)} \sum_{i=1}^{N(h)}\left[Z\left(x_{i}\right)-Z\left(x_{i}+h\right)\right]^{2}
$$

...where:

$\gamma(h)$ - Semivariance function

$h$ - Step or potential difference, namely the sample interval distance

$N(h)$ - Sample log with step $h$

$Z\left(x_{i}\right)$ - Observed values of variables in the direction of $x$

$Z\left(x_{i}+h\right)$ - Observed values of variables in the direction of $x_{i}$

As a lag-increasing function, the variation in $\gamma(h)$ is expressed by the semivariable curve, the main four parameters including nugget, range, sill, and partial sill.

\section{Health Risk Evaluation Model}

The model of health risks associated with nitrate pollution is based on the model and standards from the U.S. Environmental Protection Agency (USEPA), including hazard identification, dose-effect analysis, exposure assessment, and risk characterization, and finished according to risk information from the EPA to assess the implications of pollution incidents (Ministry of Environm ental Protection, China). Nitrite nitrogen and ammonium nitrogen are non-carcinogenic and are evaluated as:

$$
T H I=\sum_{i=1}^{n} H I_{j}
$$

$$
\begin{gathered}
H I=\frac{E}{R f D} \\
E=\frac{C \times I R \times E F \times E D}{B W \times A T}
\end{gathered}
$$

...where: $\mathrm{E}$ is the exposure dose; $\mathrm{C}$ is the target material content; IR is drinking-water consumption (here designed as $2 \mathrm{~L} / \mathrm{d}$ ); EF is the exposure frequency, usually $365 \mathrm{~d} / \mathrm{a}$; $\mathrm{ED}$ is the duration of drinking water; and AT is exposure occurrence time(d), of which carcinogens are $70 \mathrm{a} \times 365 \mathrm{~d} / \mathrm{a}$ and non-carcinogens are $30 \mathrm{a} \times 365 \mathrm{~d} / \mathrm{a}$.

According to EPA standards, when the standard is 1 and the THI is more than 1 , there is a considerable risk to human health from non-carcinogens, whereas THI less than 1 indicates a low risk to human health [17].

\section{Results and Discussion}

\section{Hydrochemicial Characteristics and Evolution}

Table 1 shows that groundwater in the study area mainly has neutral $\mathrm{pH}$, with a few samples slightly alkaline, and that the classification of total dissolved solids (TDS) is appropriate for fresh water. In the phreatic water, the mean contents of $\mathrm{HCO}_{3}{ }^{-}$and $\mathrm{Ca}^{2+}$ in groundwater are high while the coefficient of variation of $\mathrm{HCO}_{3}{ }^{-}$and $\mathrm{Ca}^{2+}$ is comparatively low, which indicates that they are the stable ions in groundwater. The coefficient of variation of $\mathrm{Cl}^{-}$and $\mathrm{SO}_{4}^{2-}$ is comparatively high and the concentrations of the two are also very high, which reflects the effect of human activities, such as sewage from daily life discharged optionally, causing the content of $\mathrm{Cl}^{-}$and $\mathrm{SO}_{4}^{2-}$ to increase.

Fig. 2 shows that $\mathrm{HCO}_{3}-\mathrm{Ca}$ is the predominant groundwater hydro-chemical type, with other types including $\mathrm{HCO}_{3}-\mathrm{Ca}-\mathrm{Mg}, \mathrm{HCO}_{3}-\mathrm{Cl}-\mathrm{Ca}$, and $\mathrm{HCO}_{3}-\mathrm{Ca}-$ $\mathrm{Na}$; and that the water type is seldom influenced by the increasing content of $\mathrm{Cl}^{-}$and $\mathrm{SO}_{4}^{2-}$. Most of the samples are distributed in Zone 5, where carbonate hardness is more than 50\%. Compared with the confined water, the phreatic water samples are scattered due to its direct connection with the outside.

Groundwater alternates rapidly in the runoff zone, which causes the soluble components in the aquifer to be leached and transported by the underground runoff, such as $\mathrm{Cl}^{-}, \mathrm{SO}_{4}^{2-}, \mathrm{Na}^{+}$, and $\mathrm{K}^{+}$, etc., of which $\mathrm{Ca}^{2+}$ and $\mathrm{HCO}_{3}{ }^{-}$are the main components. While nearby the valley, namely the discharge area of groundwater, evaporation is relatively obvious, soluble salt (such as $\mathrm{NaCl}$ ) content increases, and the hydro chemical types are relatively complex.

\section{Spatial Distribution Characteristics of $\mathrm{NO}_{3}-\mathrm{N}$}

Table 2 shows statistical analysis characteristics of the $\mathrm{NO}_{3}-\mathrm{N}, \mathrm{NO}_{2}-\mathrm{N}$, and $\mathrm{NH}_{4}-\mathrm{N}$ concentrations in groundwater. The results show that $\mathrm{NO}_{3}-\mathrm{N}, \mathrm{NO}_{2}-\mathrm{N}$, and $\mathrm{NH}_{4}-\mathrm{N}$ pollution has worsened since the leaching of agricultural non-point pollution into groundwater. 
Table 1. Statistical parameters of groundwater chemical contents (mg/L, $\mathrm{pH}$ unconcluded).

\begin{tabular}{|c|c|c|c|c|c|c|c|c|c|c|}
\hline \multirow{2}{*}{ item } & \multicolumn{4}{|c|}{ Quaternary phreatic water } & \multicolumn{4}{c|}{ Quaternary confined water } \\
\cline { 2 - 13 } & Min. & Max. & mean & $\begin{array}{c}\text { standard } \\
\text { deviation }\end{array}$ & $\begin{array}{c}\text { Coefficient of } \\
\text { variation (\%) }\end{array}$ & Min. & Max. & mean & $\begin{array}{c}\text { standard } \\
\text { deviation }\end{array}$ & $\begin{array}{c}\text { Coefficient of } \\
\text { variation }(\%)\end{array}$ \\
\hline TDS & 233.4 & 942.3 & 442.0 & 221.1 & 50.02 & 196.2 & 787.0 & 429.2 & 130.8 & 30.47 \\
\hline $\mathrm{K}^{+}$ & 1.1 & 2.9 & 1.8 & 0.5 & 26.38 & 0.5 & 5.5 & 1.3 & 0.7 & 54.12 \\
\hline $\mathrm{Na}^{+}$ & 14.8 & 117.7 & 44.3 & 29.6 & 66.72 & 11.5 & 60.1 & 27.9 & 10.2 & 36.77 \\
\hline $\mathrm{Ca}^{2+}$ & 38.7 & 140.6 & 75.7 & 33.8 & 44.71 & 30.4 & 193.0 & 94.4 & 32.2 & 34.14 \\
\hline $\mathrm{Mg}^{2+}$ & 8.4 & 59.0 & 25.0 & 17.5 & 69.93 & 7.9 & 39.8 & 20.7 & 8.4 & 40.45 \\
\hline $\mathrm{Cl}^{-}$ & 0.0 & 223.7 & 57.2 & 65.9 & 115.24 & 2.6 & 123.7 & 32.9 & 32.0 & 97.34 \\
\hline $\mathrm{SO}_{4}^{2-}$ & 2.8 & 177.9 & 50.8 & 61.5 & 121.08 & 0.9 & 179.4 & 34.3 & 39.0 & 113.71 \\
\hline $\mathrm{CO}_{3}^{2-}$ & 0.0 & 8.9 & 0.9 & 2.4 & 260.06 & 0.0 & 8.6 & 1.5 & 2.3 & 148.80 \\
\hline $\mathrm{HCO}_{3}^{-}$ & 108.7 & 450.1 & 299.9 & 121.2 & 40.42 & 149.7 & 543.3 & 348.7 & 98.8 & 28.33 \\
\hline $\mathrm{pH}^{2-}$ & 6.7 & 8.3 & 7.4 & 0.1 & 1.67 & 7.0 & 8.0 & 7.5 & 0.2 & 3.03 \\
\hline hardness & 145.1 & 574.0 & 292.5 & 146.5 & 50.08 & 107.8 & 607.8 & 321.1 & 108.4 & 33.77 \\
\hline
\end{tabular}

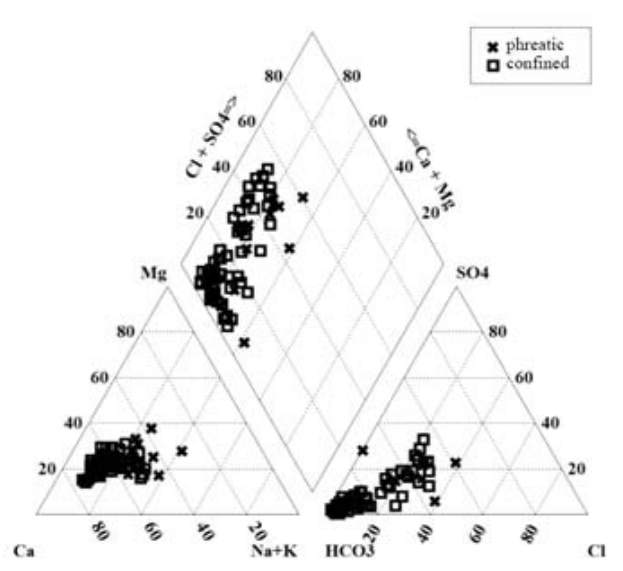

Fig. 2. The Piper trilinear charts of groundwater hydrochemical types in the study area.

In Table 2, the over standards rate of $\mathrm{NO}_{3}-\mathrm{N}$ is the largest $(50.8 \%)$, compared with only $45.16 \%$ for $\mathrm{NH}_{4}-\mathrm{N}$ and $20.78 \%$ for nitrite. The variation coefficient of $\mathrm{NO}_{3}-\mathrm{N}$, $\mathrm{NH}_{4}-\mathrm{N}$, and $\mathrm{NO}_{2}-\mathrm{N}$ is $183.57 \%, 293.54 \%$, and $235.13 \%$, respectively. It shows obvious spatial variation and distribution. The findings demonstrate the necessity of studying nitrate pollution, as this is the most serious form of pollution and shows strong spatial variation.

Using Kriging and choosing 0, 1, or 2 order of the trend effect parameter to calculate the interception error, we then determined the optimal model. The selection criteria are as follows: mean standardized error (ME) close to zero, root-mean-square is minimum, average standardized error (ASE) close to root-mean-square standardized error (RMSSE), and root-mean-square standardized error close to 1 . Tendency parameters and interpolation error are listed in Table 3.
Table 2. Statistical analysis of nitrogen in groundwater.

\begin{tabular}{|c|c|c|c|}
\hline Inspection term & $\mathrm{NO}_{3}-\mathrm{N}$ & $\mathrm{NO}_{2}-\mathrm{N}$ & $\mathrm{NH}_{4}-\mathrm{N}$ \\
\hline Max (mg/L) & 211.77 & 0.59 & 15.75 \\
\hline Min (mg/L) & 0 & 0 & 0 \\
\hline Average (mg/L) & 21.57 & 0.023 & 0.50 \\
\hline Detection rate (\%) & 86.00 & 62.36 & 55.9 \\
\hline Over standard rate (\%) & 50.80 & 20.78 & 45.16 \\
\hline Standard deviation & 35.27 & 0.068 & 1.18 \\
\hline $\begin{array}{c}\text { Variation coefficient } \\
(\%)\end{array}$ & 183.57 & 293.54 & 235.13 \\
\hline
\end{tabular}

According to the selection criteria for the optimal model parameters, and considering the interpolation error, $\mathrm{NO}_{3}-\mathrm{N}$ distribution is best fitted to the second-order spherical model. Then the model parameters are revised by the second-order spherical model. The optimal model is established by means of a fitted semivariance function with the model index corrected according to interpolation error. The optimal semivariance function model and parameters are listed in Table 4.

From Table 4, the nugget value of $\mathrm{NO}_{3}-\mathrm{N}$ is 2.423 , which indicates that the concentration shows spatial variability. The partial base station value is 1.793, indicating that the spatial variability is due to nonrandom factors. The basal effect is 0.575 , which signifies that the $\mathrm{NO}_{3}-\mathrm{N}$ distribution with medium spatial variability is due to regional hydrogeological conditions and human activity, in which the latter is obvious. The spatial variation of $\mathrm{NO}_{3}-\mathrm{N}$ in groundwater shows that this form of pollution is driven by both natural factors and human activities, of which the latter is the main and direct factor. 
Table 3. Statistics for model parameters and interpolation error.

\begin{tabular}{|c|c|c|c|c|c|c|}
\hline \multirow{2}{*}{ Order of trend } & \multirow{2}{*}{ Model type } & \multicolumn{5}{|c|}{ Forecast error } \\
\hline & & $\mathrm{ME}$ & RMSE & MSE & RMSSE & ASE \\
\hline \multirow{3}{*}{ None } & Gaussian & 1.707 & 157.854 & 0.011 & 1.003 & 157.687 \\
\hline & Spherical & 1.412 & 158.040 & 0.009 & 1.008 & 156.987 \\
\hline & Exponential & -2.172 & 169.527 & -0.007 & 1.120 & 150.304 \\
\hline \multirow{3}{*}{ First } & Gaussian & -1.875 & 166.509 & -0.006 & 1.124 & 148.089 \\
\hline & Spherical & -1.605 & 167.482 & -0.003 & 1.153 & 148.124 \\
\hline & Exponential & -1.343 & 166.064 & -0.005 & 1.103 & 149.300 \\
\hline \multirow{3}{*}{ Second } & Gaussian & -2.516 & 168.473 & -0.008 & 1.104 & 150.885 \\
\hline & Spherical & -0.431 & 160.649 & -0.001 & 1.049 & 152.773 \\
\hline & Exponential & -1.791 & 165.481 & -0.007 & 1.082 & 151.727 \\
\hline
\end{tabular}

Table 4. Optimal semivariance model and parameters.

\begin{tabular}{|c|c|c|c|c|c|c|c|c|}
\hline \multirow{2}{*}{ Trend types } & \multirow{2}{*}{ Model type } & \multicolumn{2}{|c|}{ Range } & Anisotropy & Angle & Nugget & $\begin{array}{c}\text { Partial } \\
\text { sill }\end{array}$ & $\begin{array}{c}\text { Substrate } \\
\text { effect }\end{array}$ \\
\cline { 3 - 7 } & Major semi axis & Minor semi axis & ratio & & & & \\
\hline None & Exponential & 1.098 & 0.366 & 2.998 & 75.059 & 2.423 & 1.793 & 0.575 \\
\hline
\end{tabular}

Then the spatial distribution of nitrate-nitrogen in groundwater was obtained using the Kriging method by ArcGIS (Fig. 3).

Based on groundwater quality standards [25], a nitrate nitrogen concentration $>20 \mathrm{mg} / \mathrm{L}$ is categorized as grades IV and V, whereas lower concentrations are categorized as grades I, II, and III. From Fig. 3, the study area displays serious and widespread nitrogen pollution, especially grade $\mathrm{V}$, which is distributed most widely. The region of poor groundwater quality accounts for $62 \%$ of the study area, and is distributed mainly in the eastern middle high plain, including Mingshui, Wangkui, Zhaozhou, Hailun, and Bayan County. The lightly polluted areas are distributed sporadically west of the alluvial-polluvial plain, such as the cities of Anda and Daqing, and Zhaoyuan.

The spatial variation of nitrate nitrogen in groundwater shows that this form of pollution is driven by both natural factors and human activity, of which the latter is the main and direct factor. The transportation ability, pathways, and enrichment of nitrate are determined by the surrounding environment. The areas with groundwater quality of grades IV and V are the major rice-producing areas. The large crop area, considerable fertilizer inputs, and high water table lead to increasing concentrations of nitrate nitrogen in groundwater, as nitrogen is easily leached from fertilizers into groundwater by rainfall and irrigation. In addition, the regional unsaturated zone consists of sand and well-sorted sand gravel, which has weak adsorption and a capacity to degrade nitrate nitrogen. The near-surface unsaturated zone decreases the time required for pollutants to enter the aquifer and inhibits the assimilative capacity, thereby increasing pollution risk. The precipitation infiltration coefficient reached $0.3 \sim 0.7$ with high permeability, indicating that precipitation and irrigation water easily transport pollutants into groundwater. The combined outcome of these various factors is that groundwater in the study area is seriously polluted.

The areas of groundwater grades I to III are distributed in the west, where there is little cultivated land or use of fertilizers and pesticides. In the meantime, the region has a steep hydraulic gradient with a thick unsaturated zone, which inhibits the transport of nitrate pollutants into groundwater. Therefore, self-purification of groundwater is strong and water quality remains good.

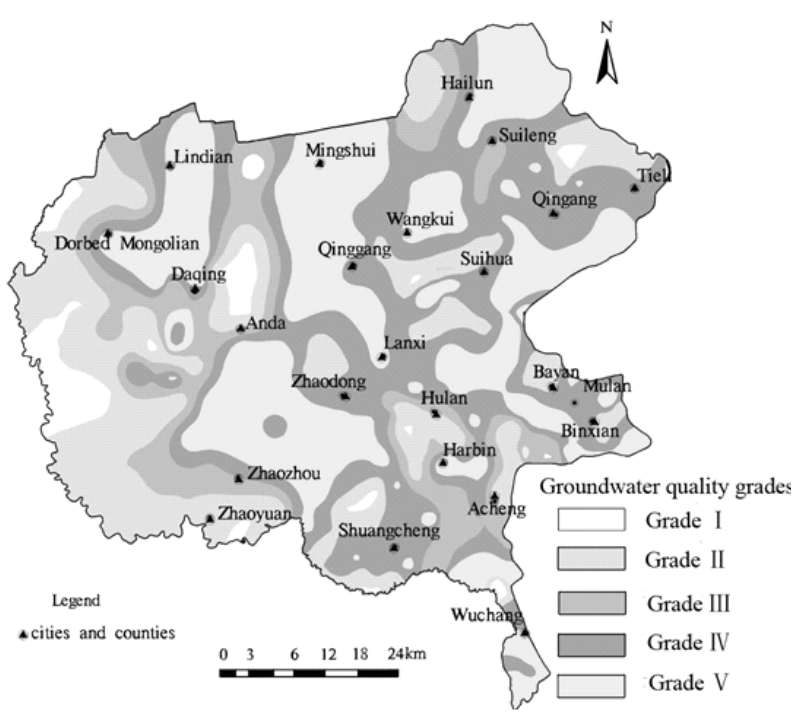

Fig. 3. Spatial distribution of nitrate-nitrogen in groundwater. 


\section{Health Risk Assessment of Nitrate Contamination in Groundwater}

According to rules of $\mathrm{NO}_{3}^{-}, \mathrm{NO}_{2}^{-}$, and $\mathrm{NH}_{4}^{+}$ transformation in groundwater, which has suffered nitrogen source pollution in the past, nitrogen concentrations exceed the limits specified in water quality standards. $\mathrm{NO}_{2}$, although the content is small, has high environmental toxicity and also represents a considerable threat to human health. Therefore, it is often used as an important indicator of nitrogen pollution.

The study area displays serious nitrate nitrogen contamination and widespread pollution of groundwater. Further analysis is therefore conducted to determine potential risks to human health. Based on the EPA classification, the reference dose of nitrate nitrogen is $1.6 \mathrm{mg} /(\mathrm{kg} \cdot \mathrm{d})$ [26], and the risk index scope of nitrate nitrogen is 0.001 to 39.075 as calculated by the health risk assessment model of non-carcinogens (types 2 and 4). There are 121 samples exceeding the standards by as much as $43.37 \%$, demonstrating that the levels of nitrate nitrogen contamination in groundwater represent a threat to human health. The corresponding non-carcinogenic chronic poisoning index of groundwater calculated by the nitrate nitrogen quality [25] grading value of groundwater and types 2 and 4 are shown in Table 5.

From Table 5, groundwater quality of class I or II has a chronic poisoning risk index of less than 0.4 , which is within the acceptable range. Groundwater quality of classes IV and $\mathrm{V}$ has a chronic poisoning index greater than 1 , which is unacceptable. Groundwater quality of class III has a chronic poisoning index of $0.400 \sim 1.572$, the upper range of which can affect human health and exceeds the acceptable range. Based on chronic poisoning index, the area is divided into high-risk and low-risk areas by ArcGIS, as shown in Fig. 4.

Fig. 4 showed that approximately $88.78 \%$ of the study area has sufficiently high concentrations of $\mathrm{NO}_{3}-\mathrm{N}$ in groundwater, which represents a high risk to human health. The high-risk area is mainly distributed in the eastern high plains and in the central low plains, including the irrigated area of intensive agriculture, and urban areas with relatively developed industry and dense populations, including Hailun, MingShui County, Anda, and Zhaozhou County. At the same time, the area is also the main source of water supply for Songnen Plain. The low-risk zone accounts for only $11.22 \%$ of the total area, and is mainly distributed in the western alluvial plain with scattered distribution in other areas.

From the spatial distributions of nitrate concentration of health risk, the high-risk area covers the area with

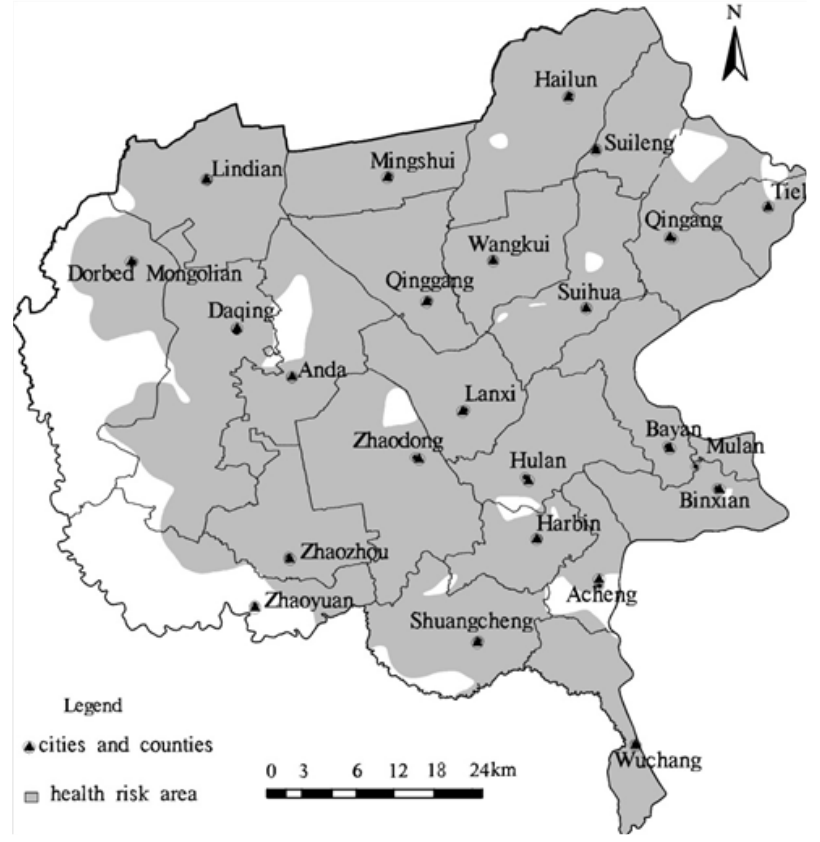

Fig. 4. Health risk evaluation of nitrate-nitrogen in groundwater.

water quality of classes IV, V, and part of class III. The remaining area is categorized as low risk, which demonstrates that the part of the area with water quality of class III also has a risk to human health despite satisfying the environmental quality standards for drinking water. Therefore, it is necessary to evaluate groundwater quality based on the health risks, combined with assessment of regional hydrogeological conditions in order to eliminate the negative effects of groundwater nitrogen pollution on human health.

\section{Conclusions}

Groundwater mainly derives from infiltration, but in some area total hardness, $\mathrm{Cl}^{-}$, and $\mathrm{SO}_{4}^{2}$ are high. Hydrochemical type is mainly $\mathrm{HCO}_{3}-\mathrm{Ca}$, and the variable coefficient in phreatic water is higher than that in confined water. Ion action is mainly associated with the action of calcite and silicate mineral weathering dissolution and ion exchange.

The findings for the three types of nitrogen $\left(\mathrm{NO}_{3}-\mathrm{N}\right.$, $\mathrm{NO}_{2}-\mathrm{N}$, and $\mathrm{NH}_{4}-\mathrm{N}$ ) concentration show that mean $\mathrm{NO}_{3}-\mathrm{N}$ concentration is $21.57 \mathrm{mg} / \mathrm{L}$, the over standards rate accounts for $50.8 \%$ of samples, which indicates serious pollution and that nitrogen levels of most groundwater samples exceed the EPA quality standards for drinking

Table 5. Quality classification and toxicity index of nitrate in groundwater.

\begin{tabular}{|c|c|c|c|c|c|}
\hline Quality classification & I & II & III & IV & V \\
\hline concentrations $(\mathrm{mg} / \mathrm{L})$ & $\leq 2$ & $\leq 5$ & $\leq 20$ & $\leq 30$ & $>30$ \\
\hline Toxicity index & $<0.151$ & $0.151 \sim 0.400$ & $0.400 \sim 1.572$ & $1.572 \sim 2.389$ & $>2.389$ \\
\hline
\end{tabular}


water. It demonstrates that the spatial variability of nitrate nitrogen is caused both by structural and random factors, and is also influenced by regional hydrogeological conditions and human activities, in which the latter is the dominant.

The area of high-risk $\mathrm{NO}_{3}-\mathrm{N}$ concentration is mainly distributed in the eastern high plains, which is located in the irrigation area with intensive agricultural activity and weak self-cleaning capacity, including Hailun, MingShui County, Anda, Zhaozhou County, and so on. The groundwater is the main source of water supply for these areas. Therefore, relevant departments should pay greater attention to issues of water quality in this area. The low-risk area accounts for only $11.22 \%$ of the total study area and is mainly distributed in the western alluvial plain.

\section{Acknowledgements}

This study was sponsored by the National Natural Science Foundation of China (No. 41072255) and the Key Laboratory of Groundwater Resources and Environment of the Ministry of Education.

\section{References}

1. ZHANG X.Y., XIN B.D., WANG X.H., GUO G.X., JI Y.Q., LU H.Y., SHEN Y.Y. Progress in research on groundwater pollution in our country. Earth and Environment. 39 (3), 415, 2011.

2. JAYALAKSHMI S., VELAPPAN E. Assessment of Water Quality Index in the St.Thomas Mount Block Using GIS and Remote Sensing. Pol. J. Environ. Stud. 24 (4), 1611, 2015.

3. TYMCZYNA L., CHMIELOWIEC-KORZENIOWSKA A., SABA L. Effect of a pig farm on the physical and chemical properties of a river and groundwater. Pol. J. Environ. Stud. 9 (2), 97, 2000.

4. CHEN S.F., WU W.L., HU K.L., Li W. The effects of land use change and irrigation water resource on contamination in shallow groundwater at county scale. Ecological Complexity. 7 (2), 131, 2010.

5. KRAUS H.H. European Parliament. Luxembourg: The Euro Pean Parliament and EC Environment Policy, Working Paper W2. 1993.

6. ALBERTIN A.R, SICKMAN J.O., PINOWSKA A., STEVENSON R.J. Identification of nitrogen sources and transformations within karst springs using isotope tracers of nitrogen. Biogeochemistry. 108 (1-3), 219, 2011.

7. YE W.M., JIN Q., HUANG Y., TANG Y.Q. Review on advance in experimental study of pollution dispersion in groundwater. Journal of Hydraulic Engineering. 36 (2), 251, 2005.

8. XU K. Progress on three forms of nitrogen contaminant transport and transform in groundwater. Geotechnical Investigation \& Surveying. 8, 32, 2012.

9. GRIZZETTI B. PRETATO U., LASSALETTA L., BILLEN G., GARNIER J. The contribution of food waste to global and European nitrogen pollution. Environment Science and Policy. 33, 186, 2013.
10. NIU Y., YIN S.Y., LIU H.L., WU W.Y., LI B.H. Use of Geostatistics to Determine the Spatial Variation of Groundwater Quality: A Case Study in Beijing>s Reclaimed Water Irrigation Area. Pol. J. Environ. Stud. 24 (2), 611, 2015.

11. CHENG J.H., ZHANG H.J., ZHANG Y.Y., CHEN Y.Z., WANG B.Y. Characteristics of Preferential Flow Paths and Their Impact on Nitrate Nitrogen Transport on Agricultural Land. Pol. J. Environ. Stud. 23 (6), 1959, 2014.

12. NESTLER A., BERGLUND M., ACCOE F., DUTA S., XUE D.M. BOECKX PAND TAYLOR P. Isotopes for improved management of nitrate pollution in aqueous resources: review of surface water field studies. Environmental Science and Pollution Research International. 18 (4), 519, 2011.

13. LIU H.B., LI Z.H., ZHANG Y.G., ZHANG W.L., LIN B. Nitrate contamination of groundwater and its affecting factors in rural areas of Beijing plain. Acta Pedologica Sinica. 43 (3), 405, 2006.

14. WANG Q.S., SUN D.B., HAO W.P., GU Y., LI Y.Z., MEI X.R., ZHANG Y.Q. Nitrate concentration distribution in groundwater of the Miyun Reservoir Watershed. Acta PedologicaSinica. 48 (1), 141, 2011.

15. BING Z.W. Study on the enrichment laws and influencing factors of arsenic and fluoride in groundwater in the Songnen plain. M.S. diss., Jilin University. 2009.

16. MENG X.L., LIANG X.J., SHENG H.X., GUO L.H. Analysis of distribution lawand influence factors of transportation of total nitrogen in groundwater in Jilin City. Research of Soil and Water Conservation. 14 (6), 85, 2007.

17. LUO Q., SUN L.N., ZHANG Y.H. Health risk assessment of persistent organochlorine pollutants in groundwater from Xihe river area. Research of Soil and Water Conservation. 18 (6), 119, 2011.

18. ZHAO H.Q., ZHAO Y.S., YANG X.K., YANG S.G., XING K., WANG C., GUO A., XIAO C.L., CHEN Z.Y., ZHANG Z.H., et al. Investigation evaluation of groundwater resources and environmental problems in Songnen plain.Beijing: Geological Publishing House. 2009.

19. ZHANG G.X., DENG W., HE Y., SALAMA R. Hydrochemical characteristics and evolution laws of groundwater in Songnen Plain, northeast China. Advances in Water Science. 17 (1), 20, 2006.

20. ZHU W. Songnen plain development trend of water quality groundwater. M.S. diss., Jilin University, 2011.

21. LI X.Q. Environmental aquatic chemistry. Changchun: Jilin Science and Technology Press. 2001.

22. CHANG J., WANG G. Major ions chemistry of groundwater in the arid region of Zhangye Basin, Northwestern China. Environmental Earth Science. 61 (3), 539, 2010.

23. YIN S.Y., WU W.Y., LIU H.L., ZHANG X.Q. Spatial variability of groundwater nitrate-nitrogen and cause analysis of its pollution for irrigation area with reclaimed water. Transactions of the Chinese Society of Agricultural Engineering. 28 (18), 200, 2012.

24. WU K.Y., WANG P., SHEN L.C., XIAO Q. Spatial and temporal variability of nitrate contaminant in groundwater in Jinfo Mt. Area, Chongqing, China. Environmental Science. 32 (11), 3247, 2011.

25. World Health Organization (WHO). Guidelines for drinking-water quality, 4rd ed. World Health Organization, Switzerland, 183, 2011.

26. ZHANG G.G. Health risk assessment of groundwater pollution in Yueyang. Journal of Water Resources and Water Engineering. 24 (6), 206, 2013. 
